\title{
INTERCULTURAL COMMUNICATION IN MILITARY MULTINATIONAL OPERATIONS
}

\author{
Lucian ISPAS*, Paul TUDORACHE** \\ *“Nicolae Bălcescu " Land Forces Academy, Sibiu, Romania \\ **National Defence University, Bucharest, Romania \\ ispaslucian04@yahoo.com, tudorache@yahoo.com
}

\begin{abstract}
The dynamics and complexity of the current operational environment requires military forces, in general, and multinational forces, in particular, new adaptation, relational-communication and action capacities to enable them to identify and combat hypothetical adversaries whose elementary features are their ability to use conventional combat actions correlated with unconventional types of combat. In this context, intercultural communication, seen not only from an internal perspective as a standard of achievement at the level of national contingents, but also externally as an instrument of establishing positive relations with the regional partners, the local population and the other actors of the operational environment, becomes a requirement essential for the performance of multinational military forces in deploying the whole spectrum of operations.
\end{abstract}

Keywords: intercultural communication, formal communication, informal communication

\section{Introductive theoretical aspects}

To begin with, in order to correctly determine the theoretical context specific to intercultural communication, it is necessary to review the generic concept of communication. Therefore, at national level, one of the most common definitions of communication is the one presented in the Communication Dictionary and it consists of a "process of transmitting information, a message between a transmitter and a receiver, via a channel; an essential mechanism in the development of human relationships ... involves an interaction and can use speech, a language, a series of symbol"[1]. Instead, internationally, "the communication process represents a chain made of identifiable links. The links in this process include the transmitter, the encoding, the environment, the decoding, the receiver and the feedback"[2]

Referring to these two definitions and carefully studying the specialized literature, we identify intercultural communication as being a "specific communication process in which reciprocal exchanges of cultural messages take place between individuals or groups belonging to different cultural communities in order to adopt a proper cultural behavior for achieving their interests and ideals"[3] or a" process of communication that takes place between people from different cultural backgrounds, whether from different countries or different subcultures of the same country"[4].

Also, the succinct presentation of these definitions supports the need to set the concept of intercultural communication, as there have been several confusions with seemingly similar concepts. An enlightening example is the confusion of intercultural communication with intercultural communication. In order to differentiate them, if in the case of intercultural communication the transmitter and the receiver are different from the point 
of view of cultural affiliation, this is not true about the intercultural communication, both having the same cultural specificity. Another aspect of their differentiation is given by the medium of communication, intercultural communication being achieved in the cultural environment specific to the transmitter and the receiver, as well as in a neutral one, while intercultural communication can occur in only one medium, either specific to the transmitter or to the receiver.

\section{Variables of intercultural communication in multinational military operations}

Once the concept of intercultural communication is clarified, we will direct our analysis to the manifestation of its specificity in the military environment. In this respect, during the conduct of operations by the military structures that consist of different national contingents, intercultural communication (ideas, attitudes, behaviors, etc.) is influenced by the following variables: time and space, personal belief and responsibility, maintaining the expressiveness of the face, nonverbal communication [5]. Table no. 1 summarizes the variables underlying the cultural differences, representing real challenges in achieving intercultural communication during the conduct of multinational military operations.

\begin{tabular}{|c|c|}
\hline VARIABLES & SIGNIFICANCE \\
\hline time and space & $\begin{array}{l}\text { - for the militaries coming from Western cultures, time has a } \\
\text { quantitative character, measured in units reflecting progress; it } \\
\text { is logical, sequential, present-oriented; it is also often linked to } \\
\text { the efficiency of the activities carried out; it has a } \\
\text { monochrome character, favoring the linear structure and } \\
\text { focusing on a single event at a time; } \\
\text { - for the militaries belonging to the cultures in the East, time is } \\
\text { perceived as having unlimited continuity, the objectives and } \\
\text { progress being irrelevant; it has a polychromic aspect, } \\
\text { meaning that the military can participate in several events at } \\
\text { the same time. }\end{array}$ \\
\hline $\begin{array}{l}\text { personal belief and } \\
\text { responsibility }\end{array}$ & $\begin{array}{l}\text { - refers to the degree to which we feel masters of our own } \\
\text { existence (specific to Western cultures), different from the } \\
\text { degree to which we view ourselves as subjects of things } \\
\text { beyond our own control (characteristic of Eastern cultures); for } \\
\text { example, during the military operations in Afghanistan, there } \\
\text { have not been few the situations in which the Romanian and } \\
\text { American militaries, interacting with the Afghans in order to } \\
\text { carry out common tasks and missions, have encountered some } \\
\text { problems in communicating as the former, waiting for action } \\
\text { and responsibility from their Afghan counterparts, considered } \\
\text { that the latter were unprofessional, obstructive or } \\
\text { unreasonable. In the same way, the Afghan soldiers, awaiting } \\
\text { respect for the natural order of things, concluded that the } \\
\text { Romanian and American militaries were coercive or irreverent } \\
\text { because they insisted on promoting their ideas about what } \\
\text { could be done or changed. }\end{array}$ \\
\hline
\end{tabular}




\begin{tabular}{|c|l|}
\hline \multirow{4}{*}{$\begin{array}{c}\text { maintaining face } \\
\text { expressivity }\end{array}$} & $\begin{array}{l}\text { - for the military, the expressivity of the face has multiple } \\
\text { meanings, being associated with ideas regarding status, } \\
\text { hierarchy/rank, internal/external relations, credibility, dignity, } \\
\text { humor, respect; } \\
\text { - in many armies, maintaining the same expression of the face } \\
\text { is of great importance, but the way it is realized differs from } \\
\text { one contingent to another. }\end{array}$ \\
\hline \multirow{5}{*}{$\begin{array}{c}\text { nonverbal } \\
\text { communication }\end{array}$} & $\begin{array}{l}\text { because when verbal messages are unclear and ambiguous, } \\
\text { there is a tendency to look for nonverbal indications that } \\
\text { support decoding them (especially when different languages } \\
\text { are used); } \\
- \text { nonverbal behaviors appear from the cultural sense of the } \\
\text { militaries, and therefore they use different systems of } \\
\text { understanding gestures related to posture, emotional } \\
\text { expression, silence, touch, etc. } \\
\text { - the importance of non-verbal communication varies from one } \\
\text { contingent to another: for example, if the US militaries lay } \\
\text { more emphasis on the literal meanings of words, it is not the } \\
\text { case for the Spanish or Portuguese militaries where } \\
\text { understanding of nonverbal components of communication is } \\
\text { significantly more important. }\end{array}$ \\
\hline
\end{tabular}

Against these variables, the intercultural communication achieved during the conduct of multinational military operations is more than a process of transmitting and receiving messages between the troops of the various national contingents. In a comprehensive way, intercultural communication requires you to understand, to make yourself understood, to convince and to positively influence the partners within the multinational military structure, the local population and the other actors in the operational environment.

\section{Forms of intercultural communication in multinational military operations}

In the multinational military environment, intercultural communication takes two forms: informal communication and formal communication. The first, the informal one, is dual, used both during military activities and in the activities that do not have a purely military nature or, in other words, for recreational purposes. Different from this, formal intercultural communication requires an approach from the perspective of vertical communication(downward and ascendant), but also from horizontal communication.

During the conduct of multinational military operations, formal intercultural communication is manifested individually and collectively in the conduct of battle rhythm activities. At the individual level, it is widely used among the militaries of different nations within the multinational force. For example, while conducting multinational military operations under NATO command, formal intercultural communication is governed by the Standard Operations Procedures (SOPS) or the Consolidated Daily Order $(C D O)$ that clearly state the "communication channels and networks, the flow and message algorithm"[7]. Collectively, it is carried out between different national units/contingencies operating either independently or within a multinational military structure, but also between the latter and other structures/forces/cells 
belonging to the other actors of the operational environment (local security forces, representatives of local government, local population, non-governmental organizations, etc.)

In the formal intercultural communication, a significant role is played by the vertical communication, with the two consecrated forms: descending and ascending. From a comparative perspective, the descending intercultural communication (from the upper echelon to the subordinate echelon) is used to transmit missions and tasks to the subordinate structures through the Operations Order $(O P O R D)$ in order to produce the effects pursued by the higher echelon. Moreover, it is characterized by an "imperative character and it develops from the top of the pyramid to the base, from the bosses to the subordinates. It uses as typical instruments: orders, provisions, regulations ..."[8]. Instead, the ascending intercultural communication (from a subordinate echelon to a higher echelon) occurs either verbally or in writing, in the form of standard reports specific to the missions, periodical situations, briefings, requests, proposals, etc. submitted by the subordinate structures to the upper echelons, pursuing two directions: "providing the subordinates with the necessary information for the planning, organization and management of the activities in the decision-making process and ... ensuring the subordinates' ability to express their wishes, needs and opinions"[9]. Despite the existence of these differences, both forms are equally used during the multinational military operations. The downward trend is required for the implementation of the multinational command (transmission of the orders for the engaging of the hypothetical adversary, the co-ordination of combat forces maneuver and fire, combat support and logistic support forces, while the ascending intercultural communication, through the transmission of standard reports, announces the state of fulfillment of the tasks or missions or makes known the state in which there is a certain maneuver (in contact with the opponent, moving towards the target, etc.) at a given moment.

The horizontal communication is another way of expressing formal intercultural communication, being as often used as the vertical one, but not between different echelons (superior, subordinate), but at the level of the same echelon, between the structures or the members of staff within them. If the vertical communication lays emphasis on the transmission of orders and dispositions (the downward component) and the reporting of their execution/stage of fulfillment (ascending component), the horizontal communication is differentiated by its nature, which is "more relaxing, friendlier. This difference is due to the fact that in this case the information circulates between people at the same hierarchical level "[10]. From another perspective, the horizontal communication represents a real support of vertical intercultural communication, the frequency of their use varying according to the action context.

In the conduct of multinational military operations, informal intercultural communication is equally important, acquiring another dimension. For example, in those operations whose intensity of fighting is small to medium, the manifestation of informal communication is more evident, especially in the conduct of shared activities, having a recreational character. If formal intercultural communication can give rise to tensions due to the intensity of fighting and the manifestation of cultural differences, informal communication can have a positive effect, as it leads to "proximity, increasing the cohesion of the group, especially if the members of the group have gone through common experiences", and the benefits of informal communication relate exclusively to the moral status of the members of the organization, materializing in: emotional relaxation; the state of work satisfaction. For commanders, the existence 
of such manifestations is evidence showing that things are done normally within the ordered structure"[11]. Specific to the multinational operational context, informal communication is even manifest in the formal framework, reducing the negative manifestation of cultural differences between national contingents and, implicitly, achieving multinational cohesion and team.

Responding to the requirements of the current operational environment and going beyond the internal horizon defined by the relations of the staff members of national contingents, the intercultural dimension of communication also requires external reporting, involving the relationship of the multicultural military force staff with the local security forces, the local population or the other actors of the operational environment. Thus, as in the first situation, the external perspective of intercultural communication (for example, the communication between the multinational military force personnel and the local population) can also have a formal and informal character. However, in this situation, formal communication is realized only through the horizontal one (there are no subordination relations between the multinational force and the local population), manifesting itself, in particular, during specific missions such as hiring local leaders(Key Leader Engagement $K L E$ ) or of cooperation between civilians and militaries (Civil Military Cooperation CIMIC). Also, by comparison with the internal perspective, in this situation the role of nonverbal communication is amplified and informal intercultural communication has to be done daily in order to gain the support of the local population, which in the context of the current military operations is seen as a center of gravity.

\section{Conclusions}

Taking into account the dynamics and complexity of the current operational environment

and analyzing the typology of potential opponents, the action of the military forces in order to combat them can no longer be thought of outside the joint, interagency, intergovernmental and multinational approach (Joint, Interagency, Intergovernmental and Multinational JIIM)[12]. Consequently, the engagement of multinational military structures in different operational environments specific to this century requires an integrating intercultural communication, equally assuming an internal and an external perspective, capable of facilitating the full spectrum of operations (FSO).

Intercultural communication with an internal character, manifested in the multinational military structure among the staff of the various national contingents, differs from the external one, the latter being realized between the personnel of the multinational military structure and the local population, as well as with the other actors in the area of operations. Even though the formal and informal aspects of intercultural communication are specific to both situations, the share of their use is different. In the case of intercultural inter force communication, the emphasis is first and foremost on vertical communication, and secondly, on the horizontal one (it has more a secondary, supportive role) and the informal one (it has a constructive result, getting the military personnel closer). With regard to the intercultural communication between the multinational military force and the local population, informal communication is at the forefront, being widely used to gain its support, while formal communication, having a secondary role, manifests itself only through horizontal communication. 


\section{References}

[1] Sultana Craia, Dictionar de comunicare, Ediția a II-a, Editura Ager, București, 2003, p. 30.

[2] Carlene Cassidy, Robert Kreitner, Supervision: Settle People Up for Success, SouthWestern Cengage Learning, Mason/Ohaio, SUA, 2010, p. 274.

[3] Mircea Cosma, Brânduşa O. Cosma, Educaţia interculturală: de la teorie la practică, Editura Universităţii Lucian Blaga, Sibiu, 2006, pp. 132-133.

[4] Anne Shibata, Intercultural Communication Concepts and Implications for Teachers, în JALT Journal, Vol. 20, No. 2, November, 1998, p. 105.

[5] Gabriella Kiss, A theoretical approach to intercultural communication, în AARMS, Volume 7, Nomber 3, 2008, p. 440.

[6] Ibidem, pp. 440-442.

[7] Constantin Afrim, Mircea Cosma, Comunicarea eficientă în conducerea operațiilor Forțelor Terestre, Editura Universităţii „Lucian Blaga”, Sibiu, 2015, p. 148.

[8] Mirela Atanasiu, Componenta non-verbală a comunicării militare, în Secțiunea 8, Comunicare publică și interculturală, din cadrul Sesiunii de comunicări științifice cu participare internațională, Strategii XXI, Universitatea Națională de Apărare „Carol I”, București, 12-13 aprilie 2007, p. 279.

[9] Constantin Afrim, Mircea Cosma,op. cit., pp. 149-150.

[10] Ibidem, p. 151.

[11] Ibidem, pp. 151-152.

[12] Paul Tudorache, Fundamente teoretice și practice privind dimensiunea interculturală a acțiunii structurilor militare multinaționale, Editura Academiei Forțelor Terestre „Nicolae Bălcescu”, Sibiu, 2018, p. 59. 